Acta Theriologica 45, Suppl. 1: 27-31, 2000.

PL ISSN 0001-7051

\title{
Chromosome studies on common shrews from northern and central parts of European Russia
}

\author{
Alexander KOZLOVSKY, Victor ORLOV, Natalia OKULOVA, \\ Julia KOVALSKAYA and Jeremy B. SEARLE
}

\begin{abstract}
Kozlovsky A., Orlov V., Okulova N., Kovalskaya J. and Searle J. B. 2000. Chromosome studies on common shrews from northern and central parts of European Russia. [In: Evolution in the Sorex araneus group: Cytogenetic and molecular aspects. J. B. Searle and J. M. Wójcik, eds]. Acta Theriologica 45, Suppl. 1: 27-31.

We report here on the karyotypes of 29 common shrews from 8 sites in northern and central European Russia. A new chromosome race for the species was found in the northernmost locality sampled and is named the Petchora race $(g i, h n, j l, k q, m o, p r)$. It is only known from the type site. Shrews from other localities belonged to races that have already been described, but the new data help to define their ranges. In particular, our new samples demonstrate that the Manturovo race is a widespread form within northern European Russia. Two shrews from Zvenigorod belonged to the 'Moscow race' as listed in Zima et al. (1996), casting doubt on the existence of the 'Zvenigorod race' as a separate entity.
\end{abstract}

Severtzov Institute of Ecology and Evolution, Russian Academy of Sciences, 117071 Moscow, Russia (AK, VO, NO, JK); Department of Biology, University of York, P.O. Box 373, York Y010 5YW, U.K. (JBS)

Key words: Sorex araneus, chromosome races, karyotypic evolution, European Russia

There have been studies on the chromosomal variation in the common shrew Sorex araneus Linnaeus, 1758 over much of its distribution (Searle and Wójcik 1998). However, there is relatively little information on the karyotypes found in northern parts of the species range. There are data for Sweden and Finland (Halkka et al. 1987, 1994, Fredga 1996a, Zima et al. 1996), but virtually nothing for northern parts of the Russian Federation. The value of such studies in northern Russia is illustrated by the brief report of Fredga (1996b) which describes a new chromosome race in the Kanin peninsula. With this in mind, we collected shrews from three sites located more than $60^{\circ} \mathrm{N}$ within European Russia. The shrews were karyotyped by standard methods and the chromosomes and chromosome races described according to the agreed nomenclature for the common shrew (Searle et al. 1991, Hausser et al. 1994).

Two of these sites were occupied by the Manturovo race already described by Bulatova et al. (2000). At Syctyvkar (Komi Republic: $61^{\circ} 30^{\prime} \mathrm{N}, 51^{\circ} 00^{\prime} \mathrm{E}$ ) the two individuals karyotyped were homozygous metacentric for the standard Manturovo 
karyotype ( $g o, h i, j l, k q, m n, p r)$ as were six of the seven individuals karyotyped at Velsk (Arkhangelsk Region: $61^{\circ} 00^{\prime} \mathrm{N}, 42^{\circ} 00^{\prime} \mathrm{E}$ ). The last individual at Velsk was homozygous metacentric for all arm combinations except $j l$, for which it was heterozygous. Such variation for $j l$ is not surprising as this chromosome displays a widespread polymorphism (Searle and Wójcik 1998). That the Manturovo race has a large range is indicated by the fact that Syctyvkar and Velsk are over $300 \mathrm{~km}$ both
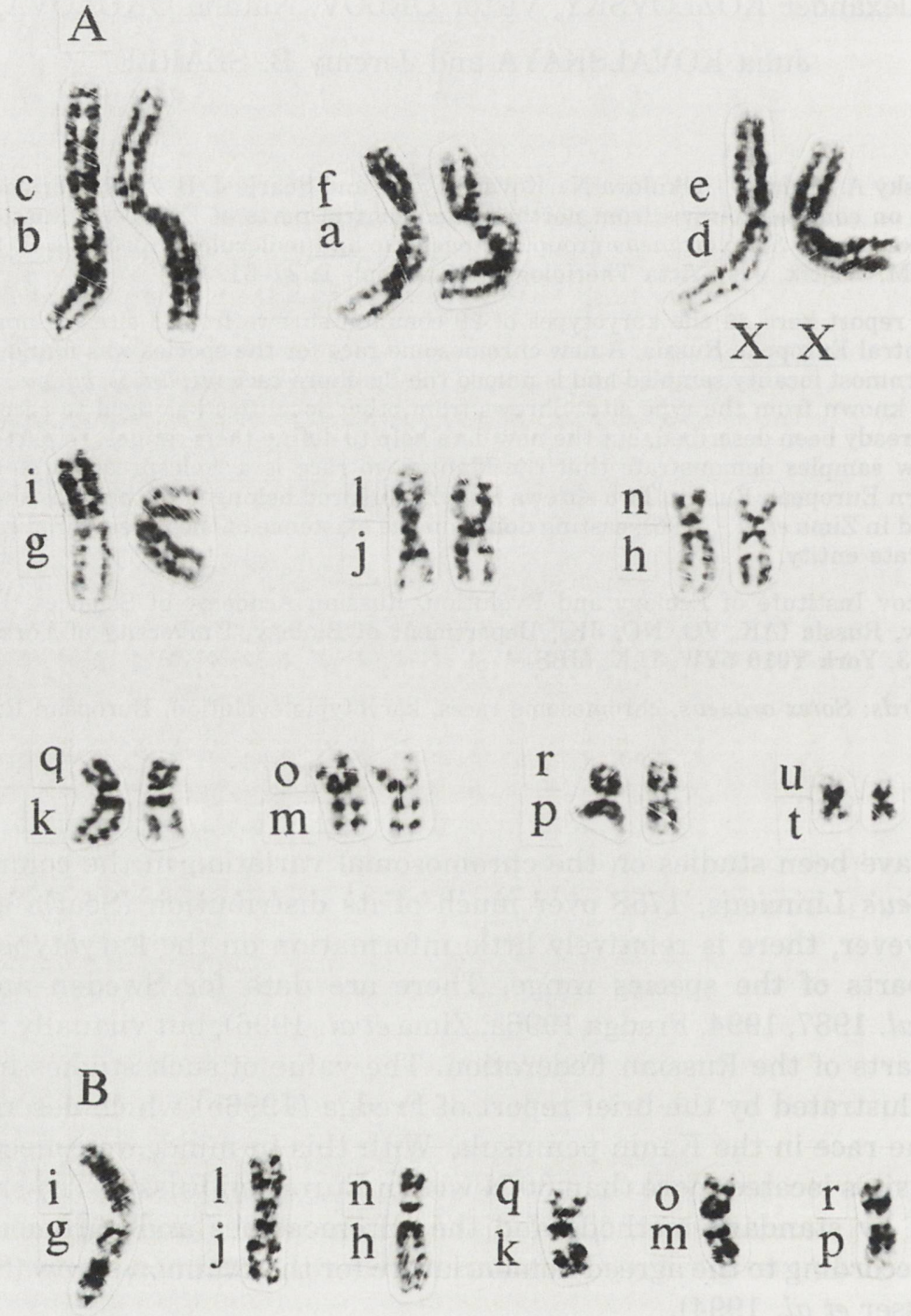

Fig. 1. G-banded karyotypes of the Petchora race. Female specimen from Petchora, 2na $=18(\mathrm{~A})$. The diagnostic metacentrics of this race (B). 
from each other and from the only previous locality for the Manturovo race (Manturovo, Kostroma Region: $58^{\circ} 30^{\prime} \mathrm{N}, 45^{\circ} 00^{\prime} \mathrm{E}$; Bulatova et al. 2000). Thus far, arm combination $j l$ is the only chromosome shown to be variable over that range.

The last of the northern sites where we karyotyped common shrews was Petchora, located close to the Arctic circle in north-eastern European Russia. The two animals karyotyped from there were both homozygous for a previously undescribed chromosomal complement (Fig. 1), which can therefore be considered to belong to a new chromosome race:

\section{Petchora race}

$\mathrm{XX} / \mathrm{XY}_{1} \mathrm{Y}_{2}, a f, b c, g i, h n, j l, k q, m o, p r, t u$



Petchora is separated by at least $500 \mathrm{~km}$ from all sites previously sampled for chromosomal variation. The nearest races are the Kanin $(g p, h i, j l, k q, m n$, or, at Kanin: $68^{\circ} 20^{\prime} \mathrm{N}, 45^{\circ} 13^{\prime} \mathrm{E}$ ), Manturovo ( $g o, h i, j l, k q, m n, p r$, at Syctyvkar: $61^{\circ} 30^{\prime} \mathrm{N}$, $51^{\circ} 00^{\prime} \mathrm{E}$ ), Serov ( $g o, h n, i p, j l, k m, q r$, at Serov: $59^{\circ} 50^{\prime} \mathrm{N}, 60^{\circ} 22^{\prime} \mathrm{E}$ ) and Novosibirsk (go, $h n, i k, j l, m p, q r$, at Hanty-Mansijsk: $61^{\circ} 00^{\prime} \mathrm{N}, 69^{\circ} 00^{\prime} \mathrm{E}$ ) (see above, Fredga 1996b, Polyakov et al. 1996, 1997). Given that none of these races are very similar to the Petchora race, its evolutionary history is not easily established. It has been proposed that the Kanin race evolved following expansion of the Manturovo race northwards and occurrence of a single whole-arm reciprocal translocation (generating $g p$ and or from go and pr) (Bulatova et al. 2000). It is possible that the Petchora race was generated likewise by north-eastwards expansion of the Manturovo race and occurrence of two different whole-arm reciprocal translocations (generating gi, $h n$ and $m o$ from go, $h i$ and $m n$ ).

In addition to the samples that we collected from the north, we karyotyped common shrews from several localities in central European Russia. These all provided new information on chromosome races that had already been described. Thus, a single new individual ( $g m, h n, i / o, j l, k r, p q$ ) was collected from the Mologa race type site to add to the accumulating information from there (Bulatova et al. 2000). Three individuals (all $g m, h n, i o, j l, k r, p q$ ) were also collected from a new Mologa race locality of Tambov $\left(52^{\circ} 40^{\prime} \mathrm{N}, 41^{\circ} 30^{\prime} \mathrm{E}\right)$; this is the first time that common shrews of the Tambov Region have been characterised.

A sample of nine individuals of the Neroosa race (Bulatova et al. 2000) was collected from Talovaya (Voronezh Region) with the following karyotypes: go, $h i, j l$, $k r, m n, p q$ (1 shrew), go, hi,j/l, $k r, m n, p q$ (1 shrew), g/o, hi,jl, $k r, m n, p q$ (4 shrews) and $g, h i, j l, k r, m n, o, p q$ ( 3 shrews). This sample helped to confirm the Neroosa race as being particularly widespread in south-western European Russia (Bulatova et al. 2000).

Particularly valuable were the new samples of the Moscow race. Following the additions and corrections made by Bulatova et al. $(1999,2000)$ to the account in Orlov et al. (1996), the Moscow race is known to be widespread in the Moscow and 
Tver Regions of central European Russia. We collected three individuals (all $g m, h i$, $j l, k r, n o, p q)$ from a third Region (Smolensk) near the town of Izdeshkovo (55 ${ }^{\circ} 10^{\prime} \mathrm{N}$, $33^{\circ} 50^{\prime} \mathrm{E}$ ). We also collected a sample of two individuals (both $g m, h i, j l, k r, n o, p q$ ) from Zvenigorod $\left(55^{\circ} 45^{\prime} \mathrm{N}, 36^{\circ} 50^{\prime} \mathrm{E}\right)$ from close to the centre of the known distribution of the Moscow race. This was particularly interesting because of previous claims by Ivanitskaya (1986) that a different karyotype is found at Zvenigorod ( $g m, h i, j l, k p, n o, q r$ ), leading Zima et al. (1996) to define a 'Zvenigorod race' separate from the 'Moscow race'. We believe that the identification by Ivanitskaya was inaccurate and that the Zvenigorod race should be deleted from future lists of chromosome races. It should be noted that chromosome arms $p$ and $r$ can be confused in some preparations, and that misidentification of these chromosomes has led to recent problems in the definition of chromosome races of the common shrew in Poland (Fedyk et al. 2000).

Taken together our work has added new information on five of the eleven chromosome races that have been described in European Russia (see Bulatova et al. 2000). The finding of a second race in the extreme north is of particular interest. Clearly, further studies may reveal even more races in these high latitudes. Here we have done little more than describe our findings. The paper by Bulatova et al. (2000) puts our work into the context of the whole of European Russia and another forthcoming article will bring together all the recent work on the Former Soviet Union in order to deduce patterns of chromosomal evolution for the whole species.

Acknowledgements: We are especially grateful to Drs N. Shchipanov and I. Kuprijanova, who kindly collected shrews. This work was supported by INTAS (93-1463) and the Russian Fund of Fundamental Investigations (97-04-48639a, 97-04-63032k).

\section{References}

Bulatova N. Sh., Bystrakova N. V., Shchipanov N. A. and Orlov V. N. 1999. Karyological differentiation of the common shrew Sorex araneus L. (Insectivora, Mammalia) from the Upper and Middle Volga river basins. Doklady Biological Sciences 366: 266-269. [English translation]

Bulatova N., Searle J. B., Bystrakova N., Nadjafova R., Shchipanov N. and Orlov V. 2000. The diversity of chromosome races in Sorex araneus from European Russia. [In: Evolution in the Sorex araneus group: Cytogenetic and molecular aspects. J. B. Searle and J. M. Wójcik, eds]. Acta Theriologica 45, Suppl. 1: 33-46.

Fedyk S., Banaszek A., Chętnicki W., Cichomska A. and Szałaj K. A. 2000. Reassessment of the range of the Drnholec race: studies on meiosis in Sorex araneus hybrids. [In: Evolution in the Sorex araneus group: Cytogenetic and molecular aspects. J. B. Searle and J. M. Wójcik, eds]. Acta Theriologica 45, Suppl. 1: 59-67.

Fredga K. 1996a. The chromosome races of Sorex araneus in Scandinavia. Hereditas 125: 123-135.

Fredga K. 1996b. A new chromosome race of the common shrew (Sorex araneus) in the Kanin peninsula, NW Russia. Hereditas 125: 247-248.

Halkka L., Kaikusalo A. and Vakula N. 1994. Revision of Sorex araneus L. chromosome nomenclature, and race N new to Finland. Annales Zoologici Fennici 31: 283-288.

Halkka L., Söderlund V., Skarén U. and Heikkilä J. 1987. Chromosomal polymorphism and racial evolution of Sorex araneus L. in Finland. Hereditas 106: 257-275. 
Hausser J., Fedyk S., Fredga K., Searle J. B., Volobouev V., Wójcik J. M. and Zima J. 1994. Definition and nomenclature of the chromosome races of Sorex araneus. Folia Zoologica 43, Suppl. 1: 1-9.

Ivanitskaya E. Yu. 1986. [A new chromosome race of the common shrew (Sorex araneus)]. [In: Proceedings of the IVth All-Union Theriological Congress, Moscow]. Moscow: 63-64. [In Russian]

Orlov V., Bulatova N., Kozlovsky A., Nadjafova R. and Searle J. B. 1996. Karyotypic variation of the common shrew (Sorex araneus) in European Russia: preliminary results. Hereditas 125: 117-121.

Polyakov A. V., Borodin P. M., Lukáčová L., Searle J. B. and Zima J. 1997. The hypothetical Old-Northern chromosome race of Sorex araneus found in the Ural Mts. Annales Zoologici Fennici 34: 139-142.

Polyakov A. V., Volobouev V. T., Borodin P. M. and Searle J. B. 1996. Karyotypic races of the common shrew (Sorex araneus) with exceptionally large ranges: the Novosibirsk and Tomsk races of Siberia. Hereditas 125: 109-115.

Searle J. B., Fedyk S., Fredga K., Hausser J. and Volobouev V. T. 1991. Nomenclature for the chromosomes of the common shrew (Sorex araneus). Mémoires de la Société Vaudoise des Sciences Naturelles 19: 13-22.

Searle J. B. and Wójcik J. M. 1998. Chromosomal evolution: the case of Sorex araneus. [In: Evolution of shrews. J. M. Wójcik and M. Wolsan, eds]. Mammal Research Institute, Polish Academy of Sciences, Białowieża: 219-268.

Zima J., Fedyk S., Fredga K., Hausser J., Mishta A., Searle J. B., Volobouev V. T. and Wójcik J. M. 1996. The list of the chromosome races of the common shrew (Sorex araneus). Hereditas 125: 97-107.

Received 21 February 2000, accepted 24 March 2000. 